IRSH 6I (20I6), pp. 5I-73 doi:I0.10I //S00208 590 I 60000 I 8

(C) 2016 Internationaal Instituut voor Sociale Geschiedenis

\title{
The Reception of E.P. Thompson in Japan: The New Left, The Making, and "Moral Economy"*
}

\author{
H I D E O I C H I H A S H I \\ Graduate School of Humanities and Social Sciences, \\ Saitama University \\ 255 Shimo-okubo, Sakura-ku, Saitama, 338-8570, Japan \\ E-mail: bridge@mail.saitama-u.ac.jp
}

\begin{abstract}
This article traces the chequered history of the reception of E.P. Thompson in postwar Japan and tries to assess what kind of impact his thoughts and ideas had on the Japanese intellectual world. In so doing, this article will draw on interviews with several academics in Japan from various generations as well as written documents. The article begins with a survey of postwar left-wing politics in Japan, against which background Thompson was introduced as a New Left thinker. It also considers the National History Movement, whose problematic legacy seemed to condition the reception of The Making of the English Working Class in Japan in the I960s. After exploring the limited reception of The Making among Japanese historians, we witness the more favourable reception of the concept of "moral economy". The article demonstrates that the rather awkward history of the reception of E.P. Thompson in Japan cannot be understood without referring to the postwar concerns of Japanese intellectuals, concerns that changed fairly dramatically in the course of time.
\end{abstract}

The first Japanese translation of The Making of the English Working Class (1963) was published in 2003, forty years after the original appeared in English. ${ }^{\mathrm{I}}$ Why did it take so long for a Japanese edition to appear? This article attempts to trace the chequered history of the reception of E.P. Thompson and his influential historical writing in postwar Japan, and thereby seeks to delineate the many faces of Thompson in Japan: New Left polemicist, labour and social historian with influential ideas on class and experience, and social and cultural historian of "moral economy".2

* I wish to thank the following academics for their willingness in offering me their knowledge, advice, and recollections: Takahiko Hasegawa, Yoshihiko Kamii, Akira Kiyasu, Kazuhiko Kondō, Takao Matsumura, Kazuo Nimura, Mitsuhiro Okamoto, Yasuhiro Sakaue, Yoshio Yasumaru, Rudi Batzell, Gabriel Winant, and Andrew Gordon.

I. E.P. Thompson, translated by Hideo Ichihashi and Kenji Haga, Ingurando Rōdosha Kaikyu no Keisei (Tokyo, 2003).

2. I regret that limited space prevents me from considering the reception of Thompson as an anti-nuclear peace activist. 


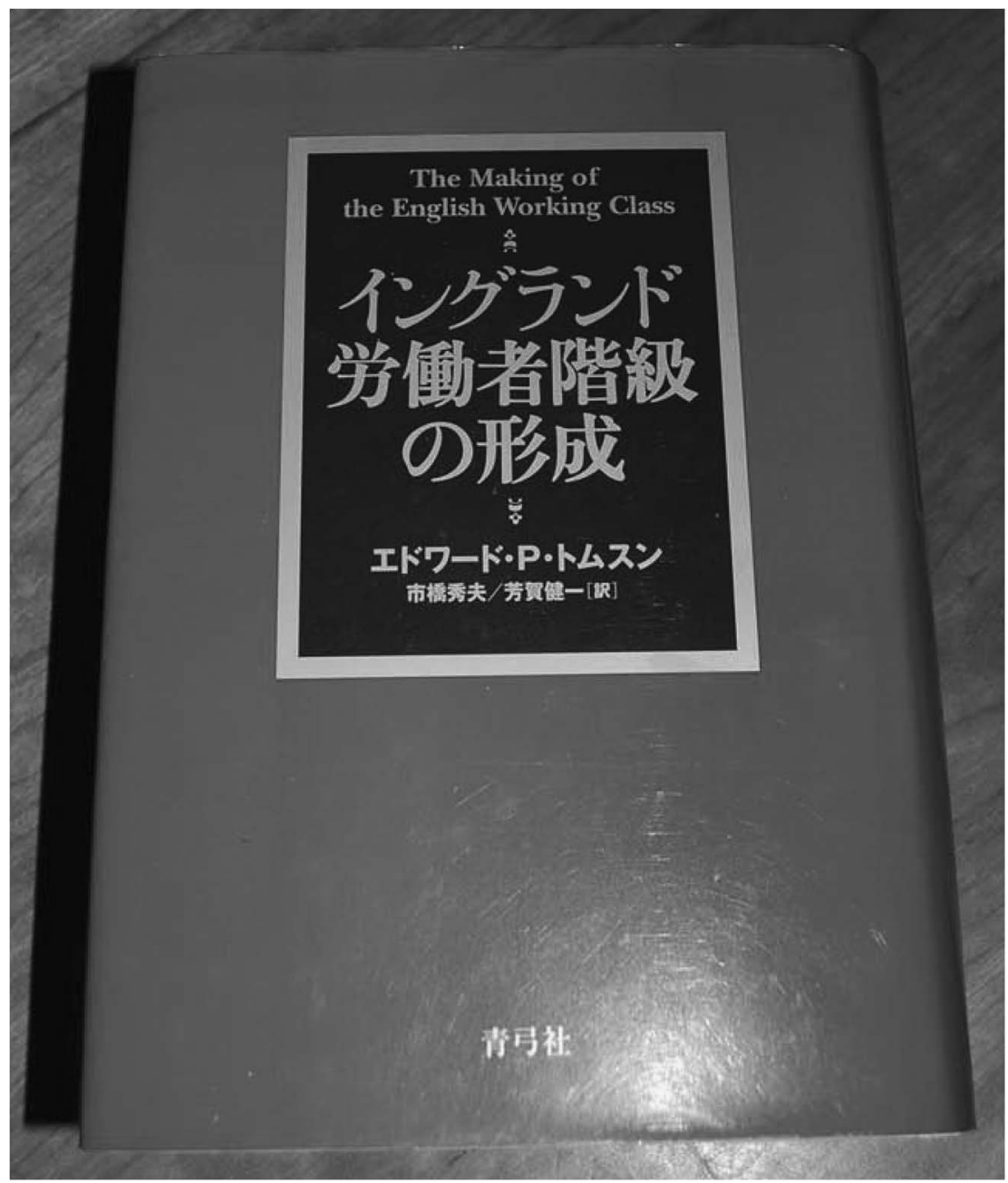

Figure I. The Japanese translation of The Making of the English Working Class.

In Japan, however, these various Thompsons do not seem to have met each other.

First, I will give a quick survey of the changing fortunes of the Japan Communist Party (JCP) during the I940s and I950s and its relationship with Japanese left-wing intellectuals, for it was against this background that Thompson as a polemicist of the British New Left was introduced in Japan. The section includes some considerations on the National History Movement (Kokuminteki Rekishigaku Undō), whose problematic legacy seemed to operate to condition the reception of The Making in I960s Japan. In the 
second section, the actual process as well as the reasons why Thompson was eagerly received by some leading Japanese social scientists and the New Left since the early I 960 is examined. The third section explores the remarkably limited reception of The Making among Japanese historians. Why was its reception so scant, and what is the significance of that? The fourth section treats the reception and spread of the extremely influential concept of "moral economy" among Japanese historians, again trying to identify the causes and circumstances of its impact among a much wider audience.

\section{POSTWAR JAPANESE COMMUNISTS}

\section{The Japan Communist Party, Soviet Marxism, and postwar Japanese left-wing intellectuals}

In the immediate postwar period in Japan, Marxism and official communism were greatly respected, commanding an unrivalled authority in the intellectual world. Before 1945, under the military regime, having abandoned their adherence to Marxism the majority of left-wing intellectuals, including many of the JCP leadership, became "tenkōsha" (converts to the right wing, who were often revolutionary supporters of the Tenno regime [the Emperor system]). Only a small minority of party members were able to keep an unflagging faith in Marxism. After the war, released from prison, those unconverted JCP members relaunched their activities under the strong influence of the Communist Party of the Soviet Union. The Soviet Union was regarded as the "mother country" of socialism, as well as one of the "Big Three" that had heroically defeated reactionary German militarism. Against this background, many Japanese left-wing intellectuals found it difficult or impossible to refute Soviet political and intellectual authority. According to Norie Ishii, a professor of Soviet history, this Soviet-influenced Marxism almost completely dominated the reawakening intellectual discourse in the early postwar period. ${ }^{3}$

The first pernicious sign of this close relationship with Stalinism appeared in I950. Until then, the JCP had pursued the line of parliamentarism and succeeded in gaining a certain amount of popular support. In the 1949 general election the JCP won thirty-five parliamentary seats (in the Lower House of the National Diet) with nearly ten per cent of the popular vote. ${ }^{4}$ However, in January I950 Stalin criticized the JCP's parliamentarism and caused great confusion and a division among party members. Around the same time, from June 1950, the Supreme Commander for the Allied Powers,

3. Norie Ishii, "'Soviet Russia no Jidai' no Rekishi-chi to Shakai Undōshi" [Historical Knowledge and Perspectives in the Era of Soviet Russia and the Journal Social Movements], in Akira Kiyasu et al. (eds), Rekishi toshite, Kioku toshite [As a History, As a Memory] (Tokyo, 2013), pp. 2 I 5-245, 232-233.

4. Masumi Ishikawa, Sengo Seijishi [Postwar Political History] (Tokyo, I995), p. 2 I 9. 
the occupational force in Japan till 1952 , tried to destroy the party with an anti-Communist "Red Purge", in which some I 3,000 party members and supporters were driven out of their jobs.' In addition, only a few weeks after the Red Purge had started, the Korean War broke out. The popular mood in Japan moved against the JCP. Making matters worse, in I95I, following a suggestion from Stalin, the JCP actually embarked on an illegal armed struggle. This merely contributed to further denting the popularity of the party. In the 1952 general election the JCP lost all its seats. ${ }^{6}$ It was not until I955 that this line was reversed and the party oriented towards parliamentary work again.

Despite all this, the belief in the authority of Marxism (including Sovietstyle Marxism) among Japanese intellectuals was not fundamentally shaken, even in the second half of the I950s. When he visited Japan in 1958 for a lecture tour, Ronald L. Meek, a British Marxist economist, observed that "there is probably no other country in the world, outside the socialist camp, in which Marxism is as academically respectable as it is in Japan".? According to him, "between one-third and one-half of Japanese university economists are Marxists of one kind or another". ${ }^{8}$ Another point Meek made is that Japanese Marxist academics were composed of diverse currents; Communist Party Marxists were in a minority, and the rest included "Socialist Party Marxists", "Christian Marxists", "Buddhist Marxists", and "strictly independent Marxists".

Overall, however, most left-wing intellectuals still placed their trust in the JCP as the "vanguard of the proletariat", which was deemed necessary for bringing about revolution. Many with a liberal or humanist orientation who had not been happy under the military regime before 1945 , and proponents of the Westernized modernization of Japan, too, acknowledged the importance of the JCP. ${ }^{9}$ One reason is probably that they regarded the party as an important political organization to combat the increasingly stronger reactionary political forces. Another reason, perhaps a more crucial one, is that they tended not to trust the ability and will of the people to change society. Many intellectuals leaning towards Marxism at that time, communists or liberals, seemed to regard ordinary Japanese people as politically passive, culturally conservative, and economically and socially preoccupied with their own families and immediate daily lives. So-called postwar intellectuals would not cast much doubt on their own perception that the people needed help from an "enlightened" elite, to lead them into a new, more civilized future.

5. Andrew Gordon, A Modern History of Japan (Oxford [etc.], 201 3, 3rd edn), p. 237.

6. Ishikawa, Sengo Seijishi, p. 220.

7. Ronald L. Meek, "Marxism in Japan”, The New Reasoner, s (I958), pp. 8 I-88, 8 I.

8. Ibid.

9. See Eiji Oguma, "Minshu" to "Aikoku” [Democracy and Patriotism] (Tokyo, 2002), p. 72. 


\section{An early "bistory from below" movement in postwar Japan}

The above description is also broadly true of those Marxist historians of Japan who presumably should have had a more sympathetic understanding of ordinary people's lives and abilities. Here, the National History Movement (Kokuminteki Rekishigaku Undō), promoted by JCP-affiliated historians between the late I940s and the first half of the I950s, is a prime example. ${ }^{\text {Io }}$ This current advocated a kind of early "history from below", and the leading historians involved in this movement argued for the importance of the people's own participation in writing the history of their own work, life, and community. The National History Movement urged historians of the younger generation and students to go "into the people", to establish a study "circle", and help people write their own history. ${ }^{I I}$ While this initiative can be analysed as a parallel to the activities of the Communist Party Historians Group (1946-1956) in Britain, it also anticipated some of the tenets of later historiographical developments in the West.

However, although there was a lot of enthusiasm initially, after around I 953 it became increasingly clear that the movement had walked into a blind alley. ${ }^{\mathrm{I2}}$ First, it was frequently the case that the very historians who

I0. The most recent re-evaluation of the movement can be found in ch. 8 of Oguma, "Minshu" to "Aikoku”.

II. The leading proponent of this movement was Shō Ishimoda (1912-1986), and his article "Mura no Rekishi, Kōjō no Rekishi" [History of a Village, History of a Factory], originally published in Rekishi Hyoron [Historical Journal], a Marxist history journal, in 1948 and reprinted in his best-selling Rekishi to Minzoku no Hakken [Discovering History and Nation] (Tokyo, 1952), was highly influential as well as controversial.

I 2. However, we should note that an important development of this early Japanese "history from below" approach could be found on the fringes of or outside the Kokuminteki Rekishigaku movement: it came from the Seikatsu Tsuzurikata Undō [Movement for Writing Life-history Composition], a pre-war educational practice to encourage schoolchildren to write accounts of their lives that attracted much attention again after the publication of the bestseller Yamabiko Gakko [A School with Mountain Spirit] in I95 I. Children were encouraged to write accounts of their lives in order to make them aware of the issues affecting their lives and their communities. In the early i950s adults, especially female workers and housewives, embarked on writing similar accounts of their own lives and work. This postwar adult Life-history Composition Movement produced fascinating works, such as those by Junji Kinoshita and Kazuko Tsurumi (eds), Haba no Rekishi [History of Mothers] (Tokyo, 1954), and Kazuko Tsurumi (ed.), Enpitsu o Nigiru Shufu [Housewives Holding a Pencil] (Tokyo, 1954). These are reminiscent of works produced much later in the context of the History Workshop movement and the Federation of Worker Writers \& Community Publishers in the UK in the I970s. Although some of the historians who had participated in Kokuminteki Rekishigaku Undo gave a helping hand to this movement, including Shō Ishimoda, many Marxist historians dismissed the Life-history Composition Movement as too un-historiographical a practice. On this last point see Shōji Ijiri, "Rekishi no Shokuba" [Workshop of History], in Shokuba no Rekishi o Tsukuru Kai (ed.), Shokuba no Rekishi [History of the Workplace] (Tokyo, I956), pp. I64-183, I74-176. A recent critical re-reading of Tsuzurikata Undō can be found in Izumi Nakaya, Sono "Minshü" to wa Dare nanoka [Who are the "People"?] (Tokyo, 2013), ch. 5. 
emphasized the importance and defence of the "national popular culture and folklore" (Minzoku no Bunka) did not really understand their complex characteristics and meaning. ${ }^{\mathrm{I}}$ At the same time, many people, workers and peasants alike, were not ready to spend their time writing history. ${ }^{14}$ Secondly, there was a tendency among the JCP leadership that its ultimate goal was not history writing, but raising the political consciousness of the people. This tended to lead to output of poor quality, making them an easy target for any detractor. Thirdly, the course of the movement was extremely vulnerable to the upheaval of JCP politics in the I950s. Around I953 some Kokuminteki Rekishigaku Undō participants began to turn against their critics with ugly sectarianism. ${ }^{\text {Is }}$ However, the JCP's sudden U-turn from armed struggle to parliamentary politics in 1955 turned the world upside down; the Kokuminteki Rekishigaku movement subsequently became associated with prior armed activities and was denounced as a cultural form of extreme left adventurism. ${ }^{16}$ Thereafter, the movement moved rapidly into decline. ${ }^{17}$

Many crucial issues and questions concerning the "history from below" approach that were proposed and debated in the Kokuminteki Rekishigaku movement were to be taken up again in the emergence of "social history", both in Japan and in Britain in the late I960s. But, for a while, the idea among Japanese left-wing historians that ordinary people should be prime agents in history and history writing was put back on the shelf. The once keen interest in people's "national culture and folklore" also disappeared after 1955 , and historians began to air their outright hostility to folklore. ${ }^{18}$ The trajectory of Kokuminteki Rekishigaku Undo should be taken into consideration when pondering the reception of The Making in Japan, for in

I3. Ishimoda admitted this self-critically; see Oguma, "Minshu” to "Aikoku”, pp. 348-349.

I4. For a reflection on the movement see, for example, Shō Ishimoda, "Shokuba no Rekishi o Megutte" [On History of the Workplace], in Shokuba no Rekishi o Tsukuru Kai, Shokuba no Rekishi, pp. 184-197.

15. Oguma, "Minshu" to "Aikoku”, pp. 346-347.

I6. See Tōma Seita's commentary, "Gojūnen no Saigetsu o bete" [After Fifty Years of Time], printed in the recent paperback reissue of Shō Ishimoda, Rekishi to Minzoku no Hakken [Discovering History and Nation] (Tokyo, 2003), pp. 458-47I, 458. For some rather hasty self-criticism written by Ishimoda and others, see Shō Ishimoda, "Rekishi Kagaku to Yuibutsuron" [Scientific History and Materialism], pp. I-53, 20-26; Nakatsuka Akira, "'Mura no Rekishi/Kōjō no Rekishi' no Hansei" [Serious Reconsideration of the 'History of a Village, History of a Factory' Movement], pp. 229-259; and Shūzō Okuda, "Rekishi no Sākuru Undō ni tsuite" [On History Writing Circles], pp. 260-286. All three articles are printed in Seita Tōma (ed.), Kōza Rekishi [Lecture Series: History], 4 vols (Tokyo, 1956), I.

17. See Yoshihiko Amino, "Sengo Rekishigaku no Gojū-nen" [Fifty Years of Postwar Historical Studies], in idem, Rekishi toshite no Sengo Shigaku [Postwar Historical Studies as History] (Tokyo, 2007), pp. 2 I-86, 5 I-54. Amino, a leading young activist historian in Kokuminteki Rekishigaku Undo left the movement in 1953 with a sense of disillusionment and became an influential social historian of the Japanese medieval period.

18. Ibid., p. 35 . 
the mid-I960s, when it was originally published, the problematic legacies of Kokuminteki Rekishigaku Undō were still felt strongly among Japanese historians.

\section{The birth of the plural New Left in Japan}

In February 1956, within months of the JCP's return to a parliamentary orientation in I955, Nikita Khrushchev made his "Secret Speech", and its contents were quickly translated and widely reported in the Japanese media. The JCP stuck to the line that while they condemned the personality cult of Stalin, there was nothing wrong with Stalinist control of the communist state and party. This thwarted the hopes of democratically oriented party members for the reform of their own party. As happened elsewhere in the world, some communist activists and intellectuals, especially among the younger generation, began to question the Stalinist principles on which the JCP's policy, strategy, and politics were based. The Hungarian uprising of 1956 further deepened their suspicions and doubts about Soviet-type Marxism. With the Khrushchev government's invasion of Hungary, it became clear that a denunciation of Stalin as an individual leader was not enough. Out of this turmoil, more than ten independent Marxist journals were launched inside and outside the JCP; ${ }^{19}$ the first generation of the Japanese New Left was born.

The first wave of the Japanese New Left, which had a clear pedigree in the communist sphere, was originally a small minority, and for a while the New Left had little effect on the JCP and its membership. ${ }^{\circ}$ However, after 1959, members left the party or were expelled in much higher numbers. The so-called Anpo struggle and its failure in 1960 accelerated this trend: many of the workers, students, and citizens who opposed Prime Minister Kishi Nobusuke's high-handed manner in renewing the Japan-US security treaty (Anpo) took part in massive street demonstrations, but the established political leadership of the left, the JCP in particular, was widely criticized for failing to channel the movement's enormous energy into viable political action. ${ }^{21}$

\section{RECEPTION OF E.P. THOMPSON AS A POLEMICIST OF THE BRITISH NEW LEFT}

It was during these post-Anpo protest years that the ideas of the British New Left, particularly E.P. Thompson's views, were anxiously introduced

19. Hirotake Koyama, Sengo no Nihon Kyōsantō [The Japan Communist Party in the Postwar Period] (Tokyo, i962), p. I78.

20. Meek, "Marxism in Japan", pp. 82-83.

2. Shinzō Shimizu, Sengo Kakushin Seiryoku [Political Forces for Postwar Renewal] (Tokyo, I966), p. 23 I; Gekkan Shakaitō Henshūbu, Nihon Shakaitō no Sanjūnen [Thirty Years of the Japan Socialist Party], 3 vols (Tokyo, 1975), II, p. 32 I. 
into the intellectual milieu of the Japanese left. The enormous energy expressed by major sections of the population against the government and the ultimate defeat of the protest movement led some Japanese Marxist intellectuals to re-examine the validity of their own analytical framework for understanding contemporary Japanese society. Around this time, just a few months before the Anpo movement came to its end, a new British left-wing journal, the New Left Review, was launched. A few Marxist intellectuals of a progressive and liberal type in Japan immersed themselves in the available writings of the newly emerging British New Left, looking for new perspectives, vision, and inspiration.

As far as I can discern, the first mention of E.P. Thompson's name in Japan came in the late spring of $196 \mathrm{I}$, in the introduction to the first issue of the short-lived New Left monthly magazine, Gendai Shiso [Contemporary Ideas]. This magazine was edited by Ikutarō Shimizu, then a Marxist social critic and an influential opinion leader in the Anpo struggle. He wrote that "movements exploring ideas for the New Left had already developed in many countries", referring to E.P. Thompson, and to Claude Bourdet in France. ${ }^{22}$ He claimed that Thompson urged "the necessity of an independent movement exploring ideas, and placed his hope on the development of the student movement". Shimizu felt that new thinking for social transformation was acutely needed after the defeat of the Anpo struggle, and observed that "in many countries, the same issues and questions exist as in Japan, and the same movements as ours exists". ${ }^{23}$

At almost the same time, Masao Maruyama (1914-1996), in a lengthy, direct discussion with Noboru Satō (1916-1993) - the leading proponent of "structural reform" theory in Japan who was about to leave the JCP - made public thoughtful comments on E.P. Thompson's two articles, "Revolution" and "Revolution Again! or Shut Your Ears and Run". ${ }^{25}$ Maruyama, a distinguished

22. Claude Bourdet was a left-wing political journalist (1909-1996).

23. Ikutarō Shimizu, "Ware Ware wa Shuppatsu suru" [We Set Off], Gendai Shisō, I: I (I96r), pp. I-6, 6. All translations from Japanese are mine.

25. Masao Maruyama and Noboru Satō, "Tōron: Gendai ni okeru Kakumei no Ronri" [Discussion: Logic for Revolution Today], in Takuichi Ikumi et al. (eds), Gendai no Ideologii [Ideology Today], 6 vols (Tokyo, 1961-1962), I, pp. I89-235. (The discussion is reprinted in Masao Maruyama, Maruyama Masao Zadan [Conversation with Maruyama Masao], 9 vols (Tokyo, I998), IV, pp. I27-I 85 .)

"Revolution" appeared in the New Left Review, 3 (1960), pp. 3-9, as well as in E.P. Thompson (ed.), Out of Apathy (London, 1960), pp. 287-308, while "Revolution Again! or Shut Your Ears and Run" was published in the New Left Review, 6 (1960), pp. I 8-3 I. In the end, two Japanese publishers subsequently printed both articles: Gōdō Shuppansha published Susumu Tamura (ed.), Gendai Kakumei eno Apurōchi [Approaches to Revolution Today] (Tokyo, 1962), while Iwanami Shoten produced E.P. Thompson (ed.), translated by Kanichi Fukuda et al., Atarashii Sayoku [New Left] (Tokyo, 1963). The former is a collection of New Left Review articles translated into Japanese, and the latter is a complete translation of Out of Apathy (1960), to which a Japanese translation of "Revolution Again! or Shut Your Ears and Run" was added. 
academic in the study of politics and political thought and arguably the most important intellectual of early postwar Japan, explained the reasons why he wanted to introduce the British New Left to a Japanese left-wing audience: ${ }^{26}$ First, the British case would contribute to and enrich "structural reform" theory in Japan, which, until that time, had referred only to the Italian case. Second, Maruyama was impressed by certain characteristics of the British New Left: its diverse membership; the active and open exchange of criticism among members; and the way in which it challenged the issues and problems presented by the new reality of the postwar world. Maruyama suggested that the New Left in Japan, whose framework of thinking had been barely updated, was extremely old fashioned, and too often preoccupied with the idea of building new sectarian organizations, could learn something refreshing from the British example.

In the exchange with Satō, Maruyama revealed the degree to which he had taken up Thompson and his New Left colleagues. Maruyama's reading of E.P. Thompson apparently found a parallel in his new reading of the emerging affluent society in postwar Japan. Maruyama repeatedly stressed how Thompson had emphasized that revolutionary eruptions were possible in every sphere of society; thus, affluence and apathy should be recognized not as negative conditions but as opportunities from which an upheaval, however small or fragmented, could be realized. Marxist intellectuals should try to find and nurture these latent potentialities and go beyond their narrow perspectives of power, human agency, and social change. Often, Maruyama argued, it was the case that conventional Marxist thinking itself contributed to strengthening the existing social order. He believed that ideas and actions, of imaginative, creative, and even of a utopian character, should be encouraged. Maruyama continued to argue that the supposedly passive masses could make a political choice, not just from their place of work and as part of the labour movement, but also from their own private spheres of daily life and leisure. A television audience, for example, Maruyama suggested, could practice a critical intervention in the existing social and cultural order by writing their own comments and criticisms to the media. ${ }^{27}$

Maruyama himself placed his hopes for the social transformation of Japan on the possibility of sharing a "radical social consciousness" among organized manual workers, on the one hand, who had been regarded as the genuine proletariat and the main subject for bringing about revolution, and the newly emerging and rapidly increasing number of white-collar workers, on the other, who had been suspected and denounced as a part of the

26. Shigeo Kawaguchi suggested that Maruyama's interest in the British New Left was born before Anpo, between 1956 and I960, without further specifying his assertion. See his "afterword" to Maruyama, Maruyama Masao Zadan, IV, pp. 325-332, 330.

27. Maruyama and Satō, "Tōron: Gendai ni okeru Kakumei no Ronri”, p. 206. 
bourgeoisie. Maruyama called upon organized workers' shared sense of identity with other people, labelling this as "citizenship", meaning that people bore a responsibility for enhancing democracy. Maruyama suggested that intellectuals and activists in Japan should pay more attention to broadening this kind of shared consciousness of democratic citizenship, and he emphasized the importance of the very process of acquiring such a sense. ${ }^{28}$

Maruyama and "structural reform" theorist Satō agreed that Thompson's ideas were different from those of the "Trotskyists", a younger, radical faction of the Japanese New Left. They criticized the Trotskyist New Left in Japan because, while they appreciated their determined radicalism, in their view the Trotskyists tended to leave behind the issue of a qualitative transformation of society. Violent revolution itself would not bring about a new society. ${ }^{29}$

Hiroshi Mizuta (b. I919), a Marxist-leaning liberal from the pre-war period and an internationally renowned scholar of the ideas of Adam Smith, also showed great interest in the British New Left. Around the end of I959, he visited E.P. Thompson's home in Yorkshire and also attended the inauguration conference of New Left Clubs in Glasgow. ${ }^{30}$ With this first-hand knowledge, he wrote articles on the early development of the British New Left for both academic and popular audiences. ${ }^{3 \mathrm{I}}$ It might seem strange that an academic specializing in the study of Adam Smith would show a great interest in the British New Left, but Mizuta was a liberal humanist heavily influenced by the ideas of Marxism in his pre-war youth. In the postwar period, he continually tried to rescue his own humanistic version of Marxism from what he saw as an over-politicized one by exploring Marxism as a body of ideas. He saw his own visions mirrored in the British New Left and E.P. Thompson.

There is evidence that historians, too, showed some interest in the then much discussed British New Left. The authoritative left-wing historical journal, Rekishigaku Kenkyu [The Journal of Historical Studies], published a short review article on the recently published Out of Apatby. The review was written by two young promising political scientists, Hidekazu Kawai

28. Ibid., p. 2 I I.

29. Ibid., pp. 223-226.

30. The first club was established in London in 1957 when the Universities and Left Review, a predecessor of the New Left Review, was published. Following the publication of the New Left Review, the number of clubs increased until there were thirty-nine at the end of 196r. Stuart Hall recalled that their purpose was to "engage with the political culture of the left on a very broad front, through argument, debate, discussion and education". See Stuart Hall, "Life and Times of the First New Left", New Left Review, 61 (2010), pp. I77-196, I 89.

31. Hiroshi Mizuta, "Igirisu no Shin-Sayoku" [British New Left], Asabi Jānaru [Asabi Journal], 3:30 (1961), pp. I4-I7; idem, "Igirisu Shin-Sayoku no Rekishi to Seikaku" [History and Characteristics of the British New Left], in Ikumi et al., Gendai no Ideologii, IV, pp. 193-2 I 8. 


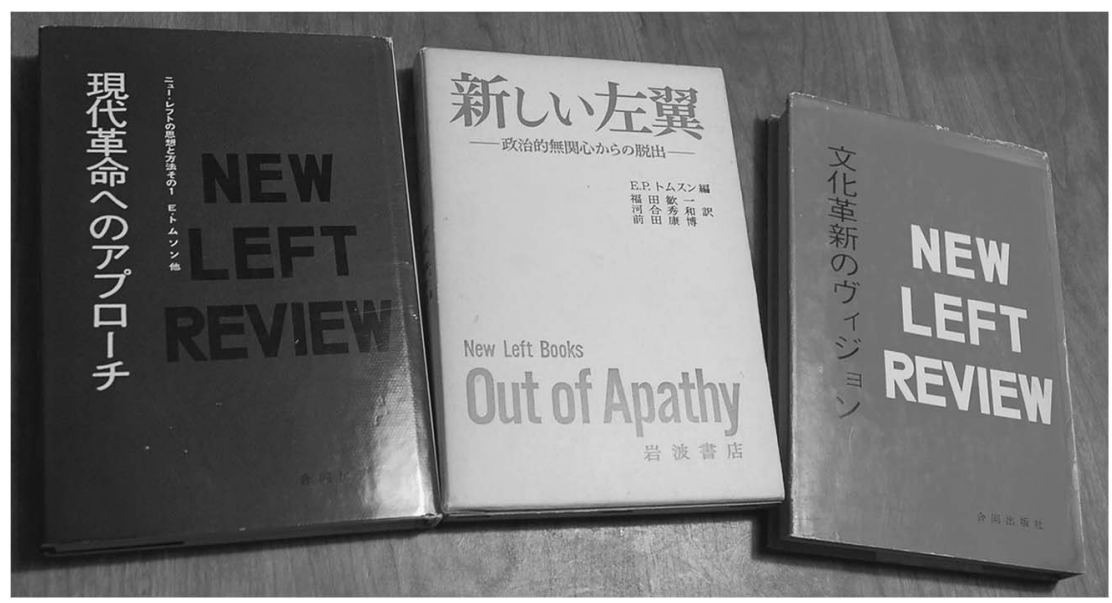

Figure 2. Japanese translations of the selected collections of New Left Review articles and Out of Apathy.

and Yasuhiro Maeda, although there were no follow-up comments, criticism, or discussion. ${ }^{32}$

The year I96I was, therefore, a time of considerable enthusiasm for the British New Left in Japan. In 1962, a translated two-volume collection of original New Left Review articles was edited by another "structural reform" advocate; ${ }^{33}$ and, as mentioned, in 1963 the first New Left book edited by Thompson, Out of Apathy, was translated and published. ${ }^{34}$

In addition, against the background of the rapidly deteriorating Cold War situation in 196I, Thompson contributed an essay to the leading Japanese opinion monthly, Sekai [The World], published in February 1962. ${ }^{35}$ This essay was written in response to a direct request from the magazine, and appears to have been published only in Japanese. In this essay, the English title of which was "Let's Cut off the Logic of the Cold War", Thompson writes that the most determined initiative for the abolition of nuclear weapons must come from non-aligned countries and independent worldwide people's movements for peace. The Campaign for

32. Hidekazu Kawai and Yasuhiro Maeda, "Igirisu no Shin-Sayoku no Hatsugen" [A Statement by the British New Left], Rekishigaku Kenkyu [The Journal of Historical Studies], 259 (1961), pp. $75-78$.

33. The first volume has already been mentioned in this article's footnote $25:$ Tamura, Gendai Kakumei e no Apprōchi; the second is idem (ed.), Bunka Kakushin no Vijon [Vision for Cultural Renewal] (Tokyo, 1962).

34. Thompson, Atarashii Sayoku.

35. E.P. Thompson, "Reisen no Ronri o Tachikirō" [Let's Cut off the Logic of the Cold War], Sekai [The World], I92 (1962), pp. I4-20. 
Nuclear Disarmament (CND) in Britain was one example of the latter, he wrote. Although CND faced grave difficulty in channelling its popular support into a viable political force, Thompson suggested that all political parties in Britain had to take into consideration the increased public sentiment in favour of nuclear disarmament. In this fashion, between 1960 and 1963 an unmistakable interest in the British New Left, and in E.P. Thompson in particular, had become evident in Japanese intellectual milieus.

\section{THE MAKING AMONG JAPANESE HISTORIANS AND INTELLECTUALS}

\section{The Making and Japanese left-wing historians of Europe}

The Making appeared in Britain in 1963, the same year that the Japanese translation of Out of Apathy was published in Japan. However, no full review of The Making appeared in Japan. It seems that the first historian who referred to it was Etsuko Yasukawa (b. 1936), a Japanese Marxist historian of British socialist thought and the labour movement. In I967, she published an article that examined the recent "turn" in British labour history since the late i950s. Yasukawa looked at this turn by focusing on the question of class consciousness: how do British Marxist labour historians explain the evolution of the apparent contemporary contentment of the English working class with the capitalist system?

In order to try to answer this question, Yasukawa examined two new, opposing historical understandings of the nature of the English working class, those of Thompson and Perry Anderson. Anderson's influential article, "Origins of the Present Crisis", had been translated into Japanese in 1965, and Thompson's fierce criticism of it, "The Peculiarities of the English", had already appeared in The Socialist Register. ${ }^{36}$ Yasukawa seemed to generally agree with Anderson's pessimistic analysis of the English working class as a historical force. While Yasukawa acknowledged Thompson's contribution in highlighting a wide range of radical traditions among the English working class, she criticized him for subscribing too much to the radical, democratic tradition of the English labour movement, thus ignoring structures that defined working-class people's work and lives. ${ }^{37}$ Yasukawa, however, was not happy with either Anderson or Thompson. Rather, she introduced a "Third Man" and hailed him as the alternative to the culturalist Thompson and Leninist Anderson. According to Yasukawa, the “Third Man's” empirical research methods were solid and

36. Perry Anderson, “Origins of the Present Crisis", New Left Review, i:23 (1964), pp. 26-53. E.P. Thompson, "The Peculiarities of the English", The Socialist Register, 2 (1965), pp. 3 I I-362. 37. Etsuko Yasukawa, "Rōdō Undō to Kaikyu Ishiki - Igirisu Rōdōshi no Senkai" [Labour Movement and Class Consciousness: A Turn in British Labour History], Shisō [Thought], 520 (1967), pp. 98-I I I, 109-I Iо. 
his argument that in England the "radical-secularist" tradition of English labour could possibly nurture Leninist historical agency was more convincing. This "Third Man", of course, was Eric Hobsbawm. ${ }^{38}$ Yasukawa decided that he was the key Marxist labour historian, who had turned the historical image of the British working class from "the Fabian workers who would try to fix their status quo within the capitalist system, to the self-conscious proletariat who would change and deny the existing social system". 39

An article that discussed The Making more substantially appeared in 1968. The author, Takehiko Satō, took up four issues: class consciousness, religious questions, the Luddites, and radicalism after the Napoleonic wars. ${ }^{40}$ He acknowledged that The Making was largely influenced by the spirit of the British New Left, and he emphasized the significance of Thompson's cultural understanding of class, which stood opposed to a more materialistic view of its origin. But Satō, too, cast doubt on Thompson's assumption that the tradition of English working-class radicalism had the potential for revolutionary social change, again siding with Hobsbawm. ${ }^{4 \mathrm{I}}$

One can certainly find academics who read The Making in the I960s in a less negative light. These were scholars interested in the history of Methodism. Methodism was singled out in Max Weber's The Protestant Ethic and the Spirit of Capitalism as one of the religious movements that led to the rise of Western capitalism. Postwar "modernist" Japanese intellectuals, such as Hisao Ōtsuka, would say that until Japanese people somehow learned a kind of Protestant ethics, the postwar rebuilding and development of the Japanese state and society would be impossible. ${ }^{42}$ In the I96os, because of the relative decline of the popularity of Marxism in the face of the rapid development of postwar Japanese capitalism, this modernist interest became more widespread than ever. Japanese historians of European social thought and religion therefore paid attention to historical works that dealt with Methodism, especially early Methodism or the Wesleyans.

38. Ibid., pp. Iо9-I Iо. Yasukawa's understanding of Hobsbawm here seems based largely on her reading of the articles collected in E.J. Hobsbawm, Labouring Men: Studies in the History of Labour (London, 1964), especially "Labour Traditions", pp. 371-385.

39. Yasukawa, "Rōdō Undō to Kaikyu Ishiki", p. Io3.

40. Takehiko Satō, "Igirisu Shoki Rōdō Undōshi no Shomondai" [Some Questions on the History of the Early British Labour Movement], Shōgaku Ronshū [The Journal of the Study of Commerce of Fukushima University], 36:4 (1968), pp. I 27-179.

4I. A reason Hobsbawm gained wider currency among Japanese historians might be put down to the fact that, contrary to Thompson and most others, he remained within the Communist Party. 42. On the postwar "modernist" thinkers in Japan, see Andrew E. Barshay, "Postwar Social and Political Thought, I945-90", in Bob Tadashi Wakabayashi (ed.), Modern Japanese Thought (Cambridge, 1998), pp. 273-355, 298-300; J. Victor Koschmann, "Intellectuals and Politics", in Andrew Gordon (ed.), Postwar Japan as History (Berkeley, 1993), pp. 395-423, 400-40I. On Hisao Ōtsuka, see Oguma, "Minshu” to “Aikoku”, pp. 90-103. 
"Progress of the Industrial Revolution in England and the Spread of Methodism"43 and "Methodism, Capitalism and Socialism"44 are two representative titles of articles published in the late I960s; and both texts referred to Thompson's arguments on Methodism put forth in The Making. This kind of historian's approach to Methodism, however, was to disappear soon, not least because of the evident fact that Japan had by then successfully industrialized without Weber's Protestant ethic.

The reasons why the reception of The Making among Japanese intellectuals of the I960s was remarkably limited can be summed up as follows. First, as is clear both in the case of Yasukawa and Satō, up to the r 970 s the ideological stance of many Japanese historians continued to be defined by a Marxist-Leninist view of class struggle, revolution, and historical agency. This was the very view that Thompson challenged in The Making, as well as in other writings such as "Revolution", published in the New Left Review. 45

Secondly, the research interests of Japanese labour historians of Britain up to the end of the I 960 s concentrated on a later period than that examined in The Making. ${ }^{46}$ The motive behind this research was to explore the historical logic of British trade unionism, which would serve as a framework by which contemporary Japanese capitalism could be analysed. Thus, I 960 s studies of British labour history in Japan were theory-oriented rather than empirical. ${ }^{47}$

Thirdly, many topics Thompson had taken up in his 900-page work tended to be regarded as trivial or unimportant. Most postwar historians in Japan had been trained in the spirit of so-called "postwar historical studies" (Sengo Rekishigaku). In "postwar historical studies", dominated by advocates of the Marxist and modernist traditions, the analysis of economic base structures was deemed most important. This was a deep-seated, almost unconscious way of thinking among Japanese left-wing intellectuals that

43. Yoshitaka Suzuki, "Igirisu Sangyō Kakumei no Shinten to Methodism-ha no Shintō" [The Development of the British Industrial Revolution and the Spread of Methodism], Shakai Keizai Shigaku [Socio-Economic History], 34 (1968), pp. I 59-1 82.

44. Junjirō Amakawa, "Methodism to Shihonshugi/Shakaishugi" [Methodism and Capitalism/ Socialism], Keizaigaku Ronkyü [The Journal of Economics of Kwansei Gakuin University], 23:2 (1969), pp. I-25.

45. Thompson, "Revolution".

46. Tomoji Onozuka, "Nihon ni okeru Igirisu Rōdōshi Kenkyu" [British Labour History in Japan], Ōhara Shakai Mondai Kenkyujo Zasshi [The Journal of the Ohara Institute for Social Research], 5 I6 (200I), pp. I-24.

47. We should, however, remember that, at least until the late I970s, it was not easy for Japanese historians of English or European history to access British or other European unpublished primary sources. With no chance to visit archives themselves, most of these historians had to rely heavily on secondary sources. 
had been nurtured in the successive debates on Japanese capitalism, Nibon Shibonshugi Ronso, since the pre-war era. Only after analysing and defining its structure and character could the most appropriate course for social change and its bearers be identified, not vice versa. It is no surprise that Hobsbawm, who wrote economic history as well as an elaborate general history of modern capitalism, was far more popular among both Marxists and modernists.

Furthermore, the school of "postwar historical studies" tended to focus only on the "progressive" elements of active human agency in history. The failure of the Kokuminteki Rekishigaku movement, already described above, enforced this; and scepticism vis-à-vis popular culture and folklore became greater than ever. In the early I960s, these scholars must have been puzzled at why Thompson took up such retrograde topics as popular religion, customs, and culture. They wondered if there were any lessons they could learn for a postwar Japan that should supposedly be marching forward to a rationally modernized future.

\section{Emergence of "people's bistory" in Japan and The Making}

But moving beyond the narrow world of historians of Britain and of European labour and social history, and shifting attention to the field of modern historical studies of Japan itself in the second half of the I960s, another striking trend comes into view: the emergence of Japanese versions of "people's history". ${ }^{8}$ These arose and developed independently from those in Britain that appeared around the same time. Nevertheless, one can find many similarities between them: a "history from below" approach; a primary concern for daily life, culture, and tradition, especially of the "common people"; an inclination towards humanist Marxism and a critique of orthodox Marxism; a heroic rescue of the poor and defeated; an aversion to theory and abstractions; and continued adherence to the political left.

Here, Daikichi Irokawa (b. I925), a pioneer of "people's history" writing in the history of Japan, deserves special mention. In his historical studies of the early Meiji period, Irokawa tried to reclaim a Japanese peasant tradition of grassroots struggle for popular democratic rights. ${ }^{49} \mathrm{He}$ literally walked around the Santama area in the western part of Tokyo, recovering new, first-rate primary sources. ${ }^{\circ}$ Although he did not seem to have read a page

48. On "people's history" writings in Japan in the I960s and I970s, see Carol Gluck, "The People in History: Recent Trends in Japanese Historiography”, The Journal of Asian Studies, 38: I (1978), pp. $25-50$.

49. Irokawa's Meiji Seishinshi [History of People's Ideas in the Meiji Period] (Tokyo, 1968) is the seminal work of "people's history" in Japan; an expanded edition, Shinpen Meiji Seishinshi [History of People's Ideas in the Meiji Period: New Edition], was published in 1973.

50. In I968, from an old warehouse in Itsukaichi City, Irokawa recovered a draft constitution of the early Meiji period (around I880) written by local civil rights activists. This so-called 
of The Making, Irokawa, a meticulous researcher and a forceful writer with a powerful rhetoric and style, could be said to be the equivalent of E.P. Thompson in Japan. ${ }^{5 \mathrm{I}}$

Similarities can be found not just in their historical approaches, but also in their personal experiences and personalities: they belonged to the same generation, were graduates of elite universities, former Communist Party members, had a strong belief in people's power to change society, expressed their undiminished support for radical popular movements, and were creative writers rather than strict academic historians.

The reason why Irokawa did not pay much attention to The Making, or to European historical studies in general, perhaps lies in his fervent nativism. ${ }^{52}$ As we have seen above, I960s Japanese historians of European society were dominated by Marxists and modernists who tended to assume that not much could be learned from inarticulate Japanese peasants of the past. Irokawa must have despised these Westernized intellectuals. He and other younger academics practising "people's history" were passionately opposed to the assumption that anything positive would come from the West.

\section{Labour historians of Japan and "bistory from below"}

Following a similar path that historians of peasant struggles, such as the abovementioned Daikichi Irokawa, had been treading in the 1960s, those historians specializing in the labour history of modern Japan began to introduce a fierce critique of Marxist and other structural explanations for the "failure" of the Japanese working class to bring about revolutionary change. The newly emerging labour history in I970s Japan was determined to take account of the actual activities and viewpoints of workers.

Among older generations one of the most influential interpretations, that advanced by Kazuo Ōkōchi (I905-I984), had been that Japanese labour movements and questions were primarily defined and characterized by the so-called "migrant worker model". ${ }^{53}$ According to Ōkōchi, Japanese workers retained a backward premodern peasant economy and culture, and this "migrant worker model" could explain all the characteristics of Japanese labour, from low wages and labour conditions to the weakness of trade union movements.

"Itsukaichi Draft Constitution" is regarded as the most important written constitution drawn up by the people in the period, for it contains wide-ranging human rights articles.

5I. Professor Kazuhiko Kondō, in an interview conducted by the author of this article, recalled that, in his youth, he had felt that Irokawa was a Japanese E.P. Thompson and that Thompson was a British Daikichi Irokawa.

52. See Barshay's brief assessment of Irokawa's historical approach in "Postwar Social and Political Thought, I945-90", pp. 348-349.

53. Kazuo Ōkōchi, Reimeiki no Nihon Rōdō Undō [The Dawn of the Labour Movement in Japan] (Tokyo, 1952). 
Rejecting this kind of sweeping explanation, Kazuo Nimura (b. 1934), a pioneer of the "history from below" approach to labour history emerging in the I970s in Japan, pointed out that, until then, there had been a lack of empirically sound studies that focused on labour processes and industrial relations at the level of individual factories or industries. He called for the development of "dispute studies" (soggi kenky $\bar{u}),{ }^{54}$ which would examine single labour disputes on a case-by-case basis, trying in this way to gain insights into the thoughts and consciousness of ordinary workers who rarely left accounts and documents of their own. They might also reveal the nature and characteristics of trade union movements more fully, as disputes would often expose underlying contradictions within such movements.

Without doubt, the emergence of this "history from below" approach enriched Japanese labour historiography. ${ }^{55}$ Nimura himself contributed an important study of a violent labour dispute at the Ashio mine, The Ashio Riot of $1907,{ }^{56}$ and by the end of the I970s he was certainly aware of E.P. Thompson's major writings. However, the Japanese labour historians' "history from below" approach, including Nimura's own, developed quite independently from those in Europe and the US. As Andrew Gordon writes in his preface to The Ashio Riot of 1907 , "Nimura's study should be placed chronologically and conceptually parallel to these others". ${ }^{77}$

\section{“MORAL ECONOMY” AND JAPANESE HISTORIANS}

Despite the new currents among labour historians in Japan mentioned here, Thompson has been better known in Japan as a historian of "moral economy" and "rough music" than as the author of The Making. ${ }^{8}$ "That is to say, Thompson was perceived as a social and cultural historian of pre-industrial society, rather than a labour and political historian of the early nineteenth-century English working class.

This perception in Japan paralleled Thompson's own evolution, his research interests shifting over time from the nineteenth to the eighteenth century, as

54. Kazuo Nimura, "Rōdō Undōshi (Senzenki)" [History of the Labour Movement (Pre-war Period)], in Rōdō Mondai Bunken Kenkyūkai (ed.), Bunken Kenkyū Nihon no Rōdō Mondai: Zōhoban [Historiographical Study of Labour Issues in Japan: An Enlarged Edition] (Tokyo, I97 I), pp. 288-305.

55. For example, see various articles in Rōdō Undōshi Kenkyūkai (ed.), Reimeiki Nihon Rōdō Undō no Saikentō [A Reassessment of the Dawn of the Labour Movement in Japan] (Tokyo, 1979).

56. Kazuo Nimura, The Ashio Riot of 1907: A Social History of Mining in Japan, edited by Andrew Gordon and translated by Terry Boardman and Andrew Gordon (Durham, NC, 1997), originally published in Japanese in 1988 .

57. Ibid., p. xiii.

58. The article on "moral economy" is E.P. Thompson, "The Moral Economy of the English Crowd in the Eighteenth Century", Past and Present, 50: ( (1971), pp. 76-I 36; on "rough music", idem, “'Rough Music': Le Charivari Anglais”, Annales E.S.C., 27 (1972), pp. 28 5-3 I 2. 
well as from class struggle to popular culture. The first major outcome of this was "The Moral Economy of the English Crowd in the Eighteenth Century", published in 197I. This was to be his most widely consulted academic essay in Japan, not just among students of British and European history, but also among those of the history of social movements in Japan.

In January I 973, Kazuhiko Kondō (b. 1947), then an MA student at Tokyo University, published his first long essay on popular movements in eighteenth-century Manchester, which referred to Thompson's article on moral economy, probably for the first time in Japan. Another Kondō article, which appeared in 1976 and introduced recent trends in labour and social history in Britain, had a great impact among Japanese historians. ${ }^{59}$ After introducing Hobsbawm's 1952 pioneering essay on the Luddites and the activities of the British Society for the Study of Labour History, Kondō moved on to his main focus, the contribution of E.P. Thompson. He summarized the crucial points of "The Moral Economy", placing it in the context of, and comparing it with, other relevant literature from both Britain and Japan. Thanks to the article, Japanese historians of all generations were now, perhaps for the first time, able to grasp E.P. Thompson as a historian. Adding to Kondō's efforts, other academics, too, began to write about recent trends in both labour history and social history as well as emerging new ways of history activism in the form of the "History Workshop" movement. ${ }^{60}$

There are particular societal reasons why, in I970s Japan, there was a general turn to social history, "The Moral Economy" being particularly welcomed. After the defeated student revolts at the end of the I960s, many on the left began to consider the orthodox Marxist view of revolutionary social change as no longer convincing. An assessment made clear that the direct actions of the students failed to attract wider support even among students themselves, let alone among ordinary Japanese people. Often, order on campus was restored with violent intervention from the state, without much institutional change or sensible gains for students. People continued to vote for the same old conservative party, which dominated the government without facing much of a challenge. The majority of Japanese people seemed to enjoy their relative affluence more than ever.

Among left-wing academics, the view took hold that not only the traditional understanding of revolutions was woefully inadequate, so, too, was that of

59. Kazuhiko Kondō, "Minshū Undō/Seikatsu/Ishiki: Igirisu no Shakai Undōshi Kenkyu kara” [Popular Movements, People's Lives and Their Consciousness: With Special Reference to the History of Social Movement in Britain], Shisō, 630 (1976), pp. 54-77.

60. Takao Matsumura, "Igirisu ni okeru Shakaishi Kenkyu" [Social History in Britain], in Sakae Tsunoyama (ed.), Keizaishigaku no Hattatsu [The Development of the Study of Economic History] (Tokyo, I979), pp. I I-I7I; Hideo Koga, "Igirisu ni okeru History Workshop no Katsudō" [History Workshop Movement in Britain], Rekishigaku Kenkyū [The Journal of Historical Studies], 46 I (1978), pp. 28-37. 
social change in general. Historians interested in the study of social movements in particular tried harder than ever to rethink people's direct action in the past. The Social Movements Research Group, which began to take shape in I97I, was a prime example of those young historians. The group was composed of historians, such as Akira Kiyasu, Kenichi Kinoshita, and Kazuhiko Kondō, who were mostly graduates from Tokyo University specializing in various European societies, and who would become leading historians in Japan later on. One of their main, common concerns was to try to explore the logic of each social and popular movement from within. They tried to analyse past social/popular movements further by situating them in the daily worlds in which participants actually lived.

This intellectual trend towards people's lives, culture, and rituals pushed historians to look into research findings outside their own discipline. Across the Japanese intellectual field, the r 970 s thus witnessed a surge of interest in anthropology and ethnography. ${ }^{6 \text { I }}$ Thompson's essays on "The Moral Economy" and "Rough Music" figured as models for how historians could usefully make use of anthropology and ethnography in that sense. Increasing access to non-Japanese primary sources also encouraged Japanese historians to rethink frameworks through which popular movements were analysed. A few members of the Social Movements Research Group, for example, had opportunities to study abroad for a year or two, exploring archive materials themselves, resulting in more detailed, nuanced historical explorations into people's lives and culture.

Moreover, the concept of "moral economy" allowed for a much wider understanding of a society. It can be seen as a concept similar to that of Gramscian "hegemony", through which the order of a whole society could be analysed. Kazuhiko Kondō saw the future development of historical study to be moving in this direction. He suggested that "moral economy" was not only the key to an understanding of the daily life of people but also to understanding their complicated relationship to a wider society and the state on the eve of industrialization. ${ }^{62}$

Michio Shibata (1926-20I I), a Japanese historian of an older generation specialized in modern France and Europe, took up Kondō's suggestions. Shibata published his influential study on modern European history, Kindai Sekai to Minshū Undō [Popular Movements in the Modern World], in $1983 .{ }^{63}$ In this book, Shibata, employing the "moral economy" concept,

61. On this point, see, Yoshio Yasumaru, "Sengochi no Henbō" [Changes in Postwar Knowledge and Wisdom], in idem and Akira Kiyasu (eds), Sengochi no Kanōsei [The Potential of Postwar Knowledge and Wisdom] (Tokyo, 2010), pp. 3-32, 22-30.

62. Interview conducted by the author of this article. See also Kazuhiko Kondō, Tami no Moraru [Culture and Society in Early Modern England] (Tokyo, I993), chs 3, 4, and 5.

63. Michio Shibata, Kindai Sekai to Minshū Undō [Popular Movements in the Modern World] (Tokyo, I983), pp. 2 I 5-230. 
emphasized that in eighteenth-century English popular movements people's recourse to force was not resistance to the existing social order but a warning to the authority and power of the local community. Thompson might have agreed to disagree on this particular point, but Shibata's own insight into the "moral economy" provided a model with which radical historians of Japanese peasant uprisings could re-examine their rather simplistic view that the crux of the study of popular movements lay merely in discovering people's experience of resistance to power.

From around 1984, there was a surge of interest in "The Moral Economy" among historians of Japanese popular movements and popular thought. For instance, for Takao Tsurumaki (b. I948), a leading historian of peasant revolts in Japan, the concept of "moral economy", in the variant of Michio Shibata and other Japanese scholars, was a catalyst for his critical re-evaluation of his own prior research findings and perspectives. $\mathrm{He}$ suggested that historians were now able to liberate themselves from their own modernist, progress-inflected reading of popular movements in order to discover the actual historical meanings of popular movements from within. $^{64}$

Tsurumaki first encountered the concept of "moral economy" by reading Shibata's book. Shortly after, he came across two essays written by Yoshio Yasumaru (b. 1934), a leading historian of Japanese social thought, which also employed and discussed the idea of "moral economy". 65 While Shibata exemplarily showed the usefulness of the concept in the context of European history, Tsurumaki suggested that it was Yasumaru who actually applied it, for the first time, to a historical analysis of Japanese peasant uprisings. ${ }^{66}$ Tsurumaki also gave an interesting detail about the conditions of this perception of Thompson: according to him, a research group of historians of popular movements in Japan discussed Thompson's “moral economy” essay in its fully translated but unpublished version. ${ }^{67}$ This is all the more remarkable considering that, up until then, Japanese scholars of Japanese history had generally not been interested in work done abroad. Now a whole group of scholars was making use of the "moral economy" concept. ${ }^{68}$

64. Takao Tsurumaki, "Yakaruru Mono wa Futokunaru Mono" [Those Who are Targeted for Arson Attacks are Those Who are in Want of Virtue], in idem, Kindaika to Dentōteki Minshu Sekai [Modernization and People's Traditional Worlds] (Tokyo, 1992), pp. I34-I43, I42-I 43 (this is a revised article that was originally published as "Oboegaki: Moraru Ekonomii" [A Memorandum: Moral Economy], Magei [Maguey], 6 (1985), pp. I-7).

65. Yoshio Yasumaru, "Konmintō no Ishiki Katei" [The Development of Political Consciousness among the Poor Man’s Party Membership], Shisō, 726 (1984), pp. 78-97.

66. Tsurumaki, "Yakaruru Mono wa Futokunaru Mono", p. I40.

67. Ibid., pp. I 40 and $\mathrm{I} 43$.

68. Other articles making use of the "moral economy" concept include Kotaro Iwata, "Toshi Uchikowashi no Ronri Kōzō" [Logic of Urban Riots], Rekishigaku Kenkyū [The Journal of Historical Studies], 547 (1985), pp. I I 5-I 27. 


\section{CONCLUDING REMARKS}

In 1982, even before the idea of "moral economy" started to have a wider impact among Japanese historians, another influential Thompson article, “'Rough Music': Le Charivari Anglais”, which had appeared in Annales in I972, was translated into Japanese. In general, from the early I980s, one could find an increasing number of translations of books and essays by the so-called “Annales School” in which Thompson's "Rough Music" was included. This marked another turning point in the reception of Thompson in Japan, for this article strengthened the view that Thompson was a social historian who specialized in the study of pre-industrial popular culture (rather than in the working classes of industrial capitalism).

In Japanese historiography, the I980s might be called the decade of social history, when many books and articles appeared featuring "social history" in their titles, often in order to convey the impression to readers that something new was being offered. Serious, academic historical studies of social and popular movements were more or less swallowed up in this tide. In parallel to this somewhat excessive commercialization of history, the original, basic ideas behind "moral economy" seemed to lose their power to appeal to the historical imagination. Since the end of the Cold War and the subsequent "triumph" of capitalist globalization, concepts such as resistance, social movements, and traditional customs and culture have lost much of their attractiveness. Instead, social integration, regulation, and control were new topics deemed as important and urgent. Certainly, less and less academic interest was being paid to topics such as social class, trade union movements, class struggle, and social movements.

Thus, at the moment, a Thompsonian social history of class, popular culture, and human agency would not seem to be in great demand in Japan. However, there is a concern among Japanese historians that common people and human agency in general have become less and less visible in recent historiography. ${ }^{69}$ At the same time, Japan is witnessing a widening of class differences, as well as the appearance of the "precarious proletariat" as a new group of highly vulnerable and exploited workers. This could give historians a further stimulus to conduct a deeper enquiry into historical examples of the human agency of those who are supposed to have little. An updated critical reassessment of the categories of Thompsonian social history, particularly those first presented in The Making, is therefore both indicated and desirable.

69. See, for example, Yasunari Abe's survey and discussion on the question in his "Kokumin Kokka' no Rekishigaku to Rekishi Ishiki" [History of the 'Nation State' and Historical Consciousness], in Rekishigaku Kenkyū Kai (ed.), Rekishigaku ni okeru Hōhōteki Tenkai [The Development of Methodology in Historical Studies] (Tokyo, 2002), pp. $295-308$. 


\section{TRANSLATED ABSTRACTS \\ FRENCH - GERMAN - SPANISH}

Hideo Ichihashi. La réception d'E.P. Thompson au Japon: la Nouvelle gauche, The Making et "l'économie morale".

Cet article retrace l'histoire mouvementée de la réception d'E.P. Thompson dans le Japon de l'Après-guerre, en tentant d'évaluer l'impact que les réflexions et idées de Thomson eurent sur le monde intellectuel japonais. Ce faisant, l'auteur s'inspirera d'entretiens avec divers universitaires de plusieurs générations au Japon et de documents écrits. L'article commence par un tableau de la politique de gauche de l'Après-guerre au Japon, toile de fond sur laquelle Thompson fut introduit en tant que penseur de la Nouvelle gauche. L'article étudie également le Mouvement de l'histoire nationale (Kokuminteki Rekishigaku Undō), dont l'héritage problématique sembla conditionner la réception de The Making (titre français: La Formation de la classe ouvrière anglaise) au Japon dans les années 1960. Après avoir examiné la réception limitée de The Making auprès des historiens japonais, nous assistons à la réception plus favorable du concept de "l'économie morale". L'article démontre que la réception assez étrange d'E.P. Thompson au Japon ne peut se comprendre sans référence aux préoccupations des intellectuels japonais dans l'Après-guerre, préoccupations qui changèrent considérablement au fil du temps.

Traduction: Christine Plard

Hideo Ichihashi. Die Rezeption E.P. Thompsons in Japan: Die Neue Linke, The Making und die „moralische Ökonomie”.

Dieser Beitrag rekonstruiert die wechselvolle Rezeptionsgeschichte E.P. Thompsons im Japan der Nachkriegszeit und versucht den tatsächlichen Einfluss seiner Gedanken und Ideen auf die Welt der japanischen Intellektuellen zu bewerten. Dabei wird auf Interviews mit mehreren japanischen Akademikern verschiedener Generationen ebenso zurückgegriffen wie auf schriftliche Dokumente. Der Beitrag beginnt mit einem Überblick über die Politik der Linken im Japan der Nachkriegsjahre; dies war der Hintergrund, vor dem Thompson als Denker der New Left eingeführt wurde. Der Beitrag untersucht auch die sogenannte Nationale Geschichtsbewegung (Kokuminteki Rekishigaku Undō), deren problematisches Erbe die Rezeption der The Making (deutscher Titel: Die Entstebung der englischen Arbeiterklasse) im Japan der i960er Jahre geprägt zu haben scheint. Nach einer Erörterung der beschränkten Rezeption der The Making durch japanische Historiker wendet sich der Beitrag der deutlich stärkeren Rezeption des Begriffs der „moralischen Ökonomie” zu. Der Beitrag zeigt, dass die recht verwickelte Rezeptionsgeschichte E.P. Thompsons in Japan nicht ohne Berücksichtigung der Anliegen japanischer Intellektueller während der Nachkriegszeit zu verstehen ist - Anliegen, die sich im Laufe der Zeit recht dramatisch veränderten. 
Hideo Ichihashi. La recepción de E.P. Thompson en Japón. La Nueva Izquierda, The Making y la "economía moral".

En este artículo se recorre la accidentada historia de la recepción de E.P. Thompson en el Japón posterior a la Segunda Guerra Mundial y trata de evaluar que impacto tuvieron sus pensamientos y sus ideas en el ámbito intelectual de este país. Para ello el trabajo se sustenta tanto en entrevistas realizadas a diferentes académicos japoneses de distintas generaciones como en documentos escritos. El artículo comienza con una visión general de la política de izquierdas en el Japón de postguerra frente a la que las propuestas de Thompson se presentaron como un pensador de la Nueva Izquierda. También se tiene en consideración el Movimiento por la Historia Nacional (Kokuminteki Rekishigaku Undō), cuyo legado problemático parecía influir para condicionar la recepción en Japón de la década de 1960 de The Making (título español: La formación de la clase obrera en Inglaterra). Después de analizar la limitada influencia de The Making entre los historiadores japoneses, sí podemos observar una recepción más favorable del concepto de "economía moral". El artículo pone de manifiesto que la historia algo complicada de la recepción de E.P. Thompson en Japón no puede ser entendida sin tener en cuenta su relación con las preocupaciones de los intelectuales japoneses de postguerra, preocupaciones que cambiaron de forma algo dramática en el transcurso del tiempo.

Traducción: Vicent Sanz Rozalén 